\title{
New gadolinium-substituted lead sodium apatite structure
}

\author{
Mohammed A. B. Abdul Jabar ${ }^{1}$, \\ E.I.Get'man' ${ }^{2}$ A.V.Ignatov \\ ${ }^{1}$ Department of Microbiology, College of Science, Al-Karkh University of \\ Science, Hayfa Street, Baghdad 10001, Iraq \\ ${ }^{2}$ Department of Inorganic Chemistry, Donetsk National University, \\ 24 Universitets'ka, Donets'k 83001, Ukraine
}

Received July 7, 2018

\begin{abstract}
The substitution of gadolinium by lead in the compound $\mathrm{Pb}_{8-\mathrm{x}} \mathrm{Na}_{2} \mathrm{Gd}_{\mathrm{x}}\left(\mathrm{PO}_{4}\right)_{6} \mathrm{O}_{\mathrm{x} / 2}$, in accordance with the scheme $2 \mathrm{~Pb}^{2+}+\bullet \rightarrow 2 \mathrm{Gd}^{3+}+\mathrm{O}^{2-}$ was studied by means of powder $\mathrm{X}$-ray diffraction (including the Rietveld refinement). It was established that solid solutions apatite samples are synthesized at $900{ }^{\circ} \mathrm{C}$ between the range from $x=0.0$ up to $x=1.0$. Rietveld method shows that $\mathrm{Gd}^{3+}$ is located in positions $\mathrm{Pb}(2)$, resulting in the distance in a polyhedron $\mathrm{Pb}(2)$ where the structure of apatite decreased.
\end{abstract}

Keywords: lead, apatite, gadolinium, substitution, solid solution.

\begin{abstract}
Методом порошковой дифракции рентгеновских лучей (включая уточнение Ритвельда) изучена структура соединения $\mathrm{Pb}_{8-x} \mathrm{Na}_{2} \mathrm{Gd}_{x}\left(\mathrm{PO}_{4}\right)_{6} \mathrm{O}_{x / 2}$, где гадолиний замещен свинцом в соответствии со схемой $2 \mathrm{~Pb}^{2+}+\bullet \rightarrow 2 \mathrm{Gd}^{3+}+\mathrm{O}^{2-}$. Установлено, что образцы твердых растворов апатита синтезируются при $900^{\circ} \mathrm{C}$ в диапазоне от $x=0,0$ до $x=1,0$. Метод Ритвельда показывает, что $\mathrm{Gd}^{3+}$ находится в положениях $\mathrm{Pb}(2)$.

Нова гадоліній-замісна свинцева апатитова структура. Mohammed $A$. B. Abdul Jabar, E.I.Get'man, A.V.Ignatov.

Методом порошкової дифракції рентгенівських променів (включаючи уточнення Ритвельда) вивчено структуру сполуки $\mathrm{Pb}_{8-x} \mathrm{Na}_{2} \mathrm{Gd}_{x}\left(\mathrm{PO}_{4}\right) 6 \mathrm{O}_{x / 2}$, де гадоліній заміщений свинцем відповідно до схеми $2 \mathrm{~Pb}^{2+}+\bullet \rightarrow 2 \mathrm{Gd}^{3+}+\mathrm{O}^{2-}$. Встановлено, що зразкии твердих розчинів апатиту синтезуються при $900{ }^{\circ} \mathrm{C}$ у діапазоні від $x=0,0$ до $x=1,0$. Метод Ритвельда показує, що $\mathrm{Gd}^{3+}$ знаходиться у положеннях $\mathrm{Pb}(2)$.
\end{abstract}

\section{Introduction}

Apatite (space group $\mathrm{P}_{3} / \mathrm{m}$ ) has a composition described by the formula $\mathrm{M}(1)_{4} \mathrm{M}(2)_{6}\left(\mathrm{BO}_{4}\right)_{10} \mathrm{X}_{2}$, where $\mathbf{M}(\mathbf{1})$ and $\mathbf{M}(2)$ metal cations are $\left(\mathrm{Na}^{+}, \mathrm{K}^{+}, \mathrm{Ca}^{2+}, \mathrm{Sr}^{2+}, \mathrm{Ba}^{2+}\right.$, $\mathrm{Pb}^{2+}, \mathrm{Cd}^{2+}, \mathrm{Eu}^{3+}, \mathrm{Y}^{3+}, \mathrm{La}^{3+}$, etc.), B- $\mathrm{Si}^{4+}, \mathrm{Ge}^{4+}$, $\mathrm{P}^{5+}, \mathrm{V}^{5+}, \mathrm{As}^{5+}, \mathrm{S}^{6+}, \mathrm{Cr}^{6+}$, etc.) and $\mathbf{X}$ is $\mathrm{OH}^{-}, \mathrm{F}^{-}$, $\mathrm{Cl}^{-}, \mathrm{Br}, \mathrm{I}^{-}, \mathrm{CO}_{3}{ }^{2-}, \mathrm{O}^{2-}, \mathrm{H}_{2} \mathrm{O}, \mathrm{HCO}^{3-}$, etc [1-5].

This structure type contains a diversity of isovalent and heterovalent substitutions supporting the origin of many interesting and useful properties. Because of these features, many compounds and solid solutions with the apatite structural type are widely studied and applied as biomaterials, luminescent and laser materials, sensors, solid electrolytes, sorbents, catalysts, and so on [6-9].

After that, the following systems were studied: $\mathrm{Pb}_{8} \mathrm{Na}_{2-\mathrm{x}} \mathrm{Kx}\left(\mathrm{PO}_{4}\right)_{6}, \mathrm{~Pb}_{8} \mathrm{Na}_{2-\mathrm{x}} \mathrm{K}_{\mathrm{x}}\left(\mathrm{AsO}_{4}\right)_{6}$, $\mathrm{Pb}_{8} \mathrm{Na}_{2-\mathrm{x}} \mathrm{Rb}_{x}\left(\mathrm{PO}_{4}\right)_{6}$ and $\mathrm{Pb}_{8} \mathrm{~K}_{2-x} \mathrm{Rb}_{x}\left(\mathrm{PO}_{4}\right)_{6}$ [10]. Later, it was shown that lead apatite formula can be represented as follows: 
$\left[\mathrm{Na}_{1.96(4)} \mathrm{Pb}_{2.04(2)}\right]^{4 \mathrm{f}}\left[\mathrm{Na}_{0.04(2)} \mathrm{Pb}_{5.6(2)}\right]^{6 \mathrm{~h}}\left(\mathrm{PO}_{4}\right)_{6}$ $[11,12]$.

The crystallochemical behavior of rare earth elements (REE) in minerals is largely regulated by the substitution of these elements in $\mathrm{Ca}(\mathrm{Pb}, \mathrm{Ba})$ structural positions, which depends on the monotonic decrease of their ionic radii with increasing atomic number (La-Lu). Atomic radii of rare earth elements decreases gradually due to a gradual increase in the nuclear charge. Thus, the selectivity of Ca-minerals on REE largely depends on the size of the Ca position. Light REE, as a rule, is concentrated in minerals with large $\mathrm{Ca}$ positions and heavy REE in minerals with small $\mathrm{Ca}(\mathrm{Pb}$, Ba) positions. Nevertheless, the splitting of the energy of the $4 \mathrm{f}$ orbitals in the electrostatic fields of the ligands is quite small (for the octahedral field it is usually about $1 \mathrm{~kJ} / \mathrm{mol}$ ), so the stabilization of the energies of the crystal fields is relatively unimportant in the crystal chemistry of rareearth elements [13]. This distribution of REE between two $\mathrm{Ca}(\mathrm{Pb}, \mathrm{Ba})$ positions depends on the mechanism of substitution, the difference of electronegativities, and valence bonds. The main factor remains unclear [14].

When a crystal substitutes a smaller atom (ion) for a larger one, a smaller one produces distortions (deformations) of the crystal structure. The introduction of a larger one into the position occupied by this ion entails a deformation-the expansion of the crystal, with the parameters of its unit cell increasing. On the contrary, if a smaller one is introduced into the position of the host ion, the deformation of the structure manifests itself in compression the parameters of the unit cell of the crystal decrease. Each crystal structure has its ultimate strength with respect to strains, such as tension or compression, and this determines the limit of stability of a given structure (mineral) when a solid solution is formed. If the value of deformation as a result of isomorphous substitution proves to be greater than the structure can withstand (greater than its compressive or tensile strength), chemical bonds in the crystal must break and therefore a solid solution cannot form. The magnitude of the deformation in the formation of a solid solution is determined by the difference in the sizes of atoms (ions) replacing each other, on the one hand, and the elasticity (compliance) of the structure to stretching or compression, on the other. These properties of the crystal change their size under the action of compression or expansion which are characterized by compressibility and thermal expansion.

The isomorphic capacity of the structure depends on its properties - compressibility and thermal expansion, on the one hand, and on the difference in the ionic radii of substituting elements - on the other. Ultimately, all the stresses in the solid solution structure caused by the mixing of dissimilar atoms in the same positions lead to an endothermic (costly) heat effect that lowers the stability of the solid solution. This produces exactly the same factor that acts in the opposite entropy direction and makes it difficult to form mixed crystals. If it were not, then under the influence of growth of entropy all substances, natural and artificial, there would be homogeneous mixtures of those components that are present in the system, and lose their individuality [15, 16].

There is a possibility of much larger degrees of substitution under the following scheme:

$$
2 \mathrm{~Pb}^{2+}+\bullet \rightarrow 2 \mathrm{Ln}^{3+}+\mathrm{O}^{2-},
$$

(where - is a vacancy in the structural channel) in $\mathrm{Pb}_{8} \mathrm{Na}_{2}\left(\mathrm{PO}_{4}\right)_{6}$, taking into consideration that in this apatite the hexagonal channels are free from $\mathrm{OH}^{-}$ions groups, which prevent $\mathrm{O}^{2-}$ ions from entering into the channels because of the effectiveness of electrostatic repulsion [17]. In this work, we carried an investigation of the isomorphs substitution of $\mathrm{Gd}$ for $\mathrm{Pb}$ in $\mathrm{Pb}_{8} \mathrm{Na}_{2}\left(\mathrm{PO}_{4}\right)_{6}$ under the scheme

$$
2 \mathrm{~Pb}^{2+}+\bullet \rightarrow 2 \mathrm{Gd}^{3+}+\mathrm{O}^{2-}
$$

in the compound $\mathrm{Pb}_{8-\mathrm{x}} \mathrm{Na}_{2} \mathrm{Gd}_{\mathrm{x}}\left(\mathrm{PO}_{4}\right)_{6} \mathrm{O}_{\mathrm{x} / 2}$.

\section{Experimental}

To examine isomorphous substitution in a wide range of compositions, the set of samples $\mathrm{Pb}_{8-\mathrm{x}} \mathrm{Na}_{2} \mathrm{Gd}_{\mathrm{x}}\left(\mathrm{PO}_{4}\right)_{6} \mathrm{O}_{\mathrm{x} / 2}$ with $x=0$, $0.5,1.0,1.2$ and 2.0 were synthesized by solid state reaction. All samples were synthesized according to the following reaction:

$$
\begin{gathered}
(8-x) \mathrm{PbO}+6\left(\mathrm{NH}_{4}\right)_{2} \mathrm{HPO}_{4}+\mathrm{Na}_{2} \mathrm{CO}_{3}+ \\
(x / 2) \mathrm{Gd}_{2} \mathrm{O}_{3} \rightarrow \mathrm{Pb}(8-\mathrm{x}) \mathrm{Gd}_{\mathrm{x}} \mathrm{Na}_{2}\left(\mathrm{PO}_{4}\right)_{6} \mathrm{O}_{(\mathrm{x} / 2)}+ \\
9 \mathrm{H}_{2} \mathrm{O}+\mathrm{CO}_{2}+12 \mathrm{NH}_{3} .
\end{gathered}
$$

As starting reagents for apatite synthesis, we used $\mathrm{PbO}$ (chemically pure), $\mathrm{Gd}_{2} \mathrm{O}_{3}$ $(99.99 \%), \mathrm{Na}_{2} \mathrm{CO}_{3}$ (chemically pure) and $\left(\mathrm{NH}_{4}\right)_{2} \mathrm{HPO}_{4}$ (analytical grade), which are provided by Sinbias, Research-Production Firm, LLC (Ukraine). Before use reagents 
for apatite synthesis, the reagents were heat-treated to remove adsorbed water and carbon dioxide at their storage. The choice of temperature was made on the basis of the thermal stability of substances. Lead oxide was calcined at $400{ }^{\circ} \mathrm{C}$ for $4 \mathrm{~h}$, sodium carbonate at $500{ }^{\circ} \mathrm{C}$ for $3 \mathrm{~h}$, and gadolinium oxide at $900{ }^{\circ} \mathrm{C}$ for $4 \mathrm{~h}$. Annealed reagents were cooled to room temperature in a drying chamber with freshly heated silica gel and kept in a desiccator until start weighing. A mixture of initial components with a total weight of $1 \mathrm{~g}$ was ground in a mortar for $40 \mathrm{~min}$, followed by successive annealing steps in alumina crucibles at $300{ }^{\circ} \mathrm{C}$ for $3 \mathrm{~h}$ to remove volatile substances, and it will be finally at $900{ }^{\circ} \mathrm{C}$ for $7 \mathrm{~h}$ with intermittent grindings at the last temperature step. To determine the optimum conditions of the synthesis, successive annealing was performed in the temperature range between 400-900 ${ }^{\circ} \mathrm{C}$ in steps of $100{ }^{\circ} \mathrm{C}$ and with grinding $20 \mathrm{~min}$ after each step. The duration of annealing for the last temperature step was established reaching a stable phase composition of synthesized samples, as verified by XRD analysis.

The materials synthesized were characterized by X-ray powder diffraction (XRD) and was carried out with a DRON-2 and DRON-3 diffractometers, using Ni-filtered $\mathrm{Cu} \mathrm{K}_{\alpha}$ radiation $(\lambda=1.54178)$ at a scanning rate for $2^{\circ}(2 \theta) / \mathrm{min}$ in the range $15-140^{\circ}$ at a counting time which is 3 sec for each step. For phase investigation, we used the Match program and PDF-2 database (ICCD) (International Centre for Diffraction Data) [18], as well as database PDF-4 (ASTM) (American Society for Testing and Materials).

The unit cell parameters were studied by the least-squares method based on 16 uniquely indexed independent reflections rescanned at $1^{\circ}(2 \theta) / \mathrm{min}$ in the range $16 \leq 2 \theta \leq 54^{\circ}$. The silicon was used as an external standard.

To clarify data for the crystal structure refinement by the Rietveld method, the samples were scanned in steps of $0.05^{\circ}(2 \theta)$ in the range $15^{\circ} \leq 2 \theta \leq 140^{\circ}$ with a counting time at each point step which is 3 sec. Calculation of theoretical intensities and refinement of the unit cell parameters, atomic coordinates, isotropic temperature parameters of atoms, filling factors of the correct point systems was carried out using the program FullProf.2k (version 2.80) [19] with the graphical interface WinPLOTR [20]. As starting data for the calculations, the coordi-
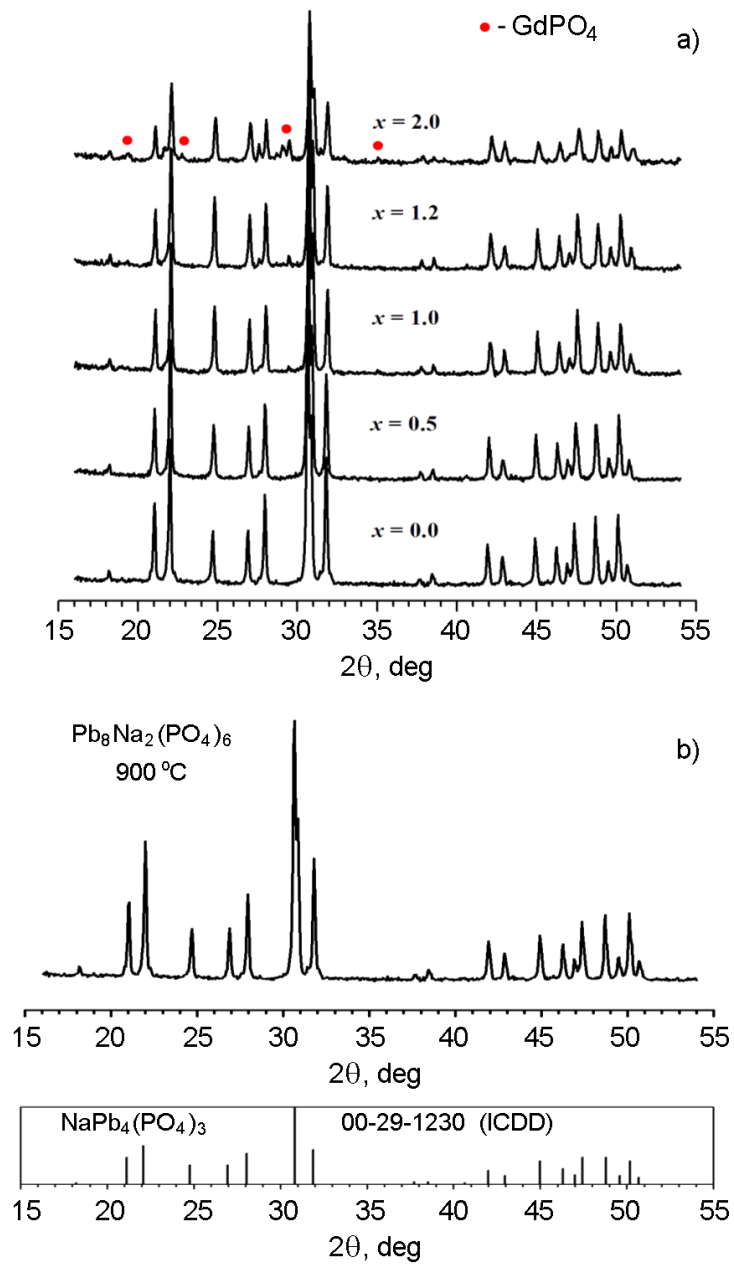

Fig. 1. (a) The X-ray diffraction patterns of $\mathrm{Pb}_{8-\mathrm{x}} \mathrm{Gd}_{\mathrm{x}} \mathrm{Na}_{2}\left(\mathrm{PO}_{4}\right)_{6} \mathrm{O}_{\mathrm{x} / 2}$, and (b) X-ray diffraction pattern of $\mathrm{Pb}_{8} \mathrm{Na}_{2}\left(\mathrm{PO}_{4}\right)_{6}$ and diffractogram the phase identification of $\mathrm{Pb}_{8} \mathrm{Na}_{2}\left(\mathrm{PO}_{4}\right)_{3}$ based on data base PDF-2 (ICDD).

nates of the corresponding atoms in the hydroxyapatite of calcium were taken [21, 22].

Transmission infrared spectra (IR) were measured by $\mathrm{KBr}$ method using a Fourier transform infrared spectroremeter (FT-IR TENSOR 27 Bruker Optics) in the wavenumber range (4000-400) $\mathrm{cm}^{-1}$. Samples were heated up to $600{ }^{\circ} \mathrm{C}$ to remove adsorbed water and then carried out on a pellet, which were prepared by crushing 1 mg samples with $600 \mathrm{mg} \mathrm{KBr}(1: 600)$ under a pressure of $900 \mathrm{MPa}$.

To determine grain shapes and size, semi-quantitative elemental analysis and element allocation on the grain surfaces, samples were performed by scanning electron microscopy with X-ray microanalysis in a scanning electron microscope JSM6490L V (JEOL, Japan) with energy dispersive spectrometer INCA Penta FETx3 (OXFORD In- 
Table. Dependence of the lattice parameters $a, c$ and $v$ on the degree of substitution in $\mathrm{Pb}_{8-\mathrm{x}} \mathrm{Gd}_{\mathrm{x}} \mathrm{Na}_{2}\left(\mathrm{PO}_{4}\right)_{6} \mathrm{O}_{\mathrm{x} / 2}$ with the measurement errors for each parameter.

\begin{tabular}{|c|c|c|c|c|c|c||}
\hline Degree of substitution $(x)$ & $a, \AA$ & $\mathrm{S} a$ & $c, \AA$ & $\mathrm{S} c$ & $v, \AA^{3}$ & $\mathrm{~S} v$ \\
\hline 0.0 & 9,73798 & 0.00232 & 7.20246 & 0.00277 & 591.4928 & 0.3623 \\
0.5 & 9,73078 & 0.00290 & 7.19040 & 0.00302 & 589.2191 & 0.4504 \\
1.0 & 9,72355 & 0.00283 & 7.17995 & 0.00296 & 585.9963 & 0.4381 \\
1.2 & 9.72208 & 0.00289 & 7.17792 & 0.00283 & 585.9989 & 0.4747 \\
2.0 & 9.72290 & 0.00295 & 7.17685 & 0.00221 & 586.0064 & 0.4805 \\
\hline
\end{tabular}

struments, England). Differences in the experimental and theoretical content of the elements do not exceed $2 \%$, which is acceptable for this method of analysis in such systems.

\section{Results and discussion}

The X-ray diffraction patterns of samples with different value $x$ obtained by solid state reaction are shown in Fig. 1. In the composition range $x=0.0$ and 0.5 , diffractogram shows only reflections of phase with the structure of apatite (reflections of pure apatite), while in the composition range $x=1.0$, 1.2 and 2.0 , reflections of the gadolinium phosphate structure $\mathrm{GdPO}_{4}$ are present on the X-ray patterns, where the intensity increases with increasing $x$.

The substitution limits of $\mathrm{Gd}$ element $\left(x_{\max }\right)$ were determined by two methods: the first method called "bend" (inflection) on a plot of the lattice parameters of elementary hexagonal unit cells ( $a$ and $c$ ) versus the degree of substitution (Fig. 2 and Table), and the second method called "disappearing phase" method [24]. As can be seen from the data of bend method, by increasing $x$, the parameters of cell $a$ and $c$ are regularly reduced, and they remain practically constant at $x=1.0$. Then, they remain unchanged up to $x=2.0$ (the total changes of the parameters do not exceed much the measurement error $( \pm 0.003 \AA))$. The obtained results for parameters $a$ and $c$ show that the substitution of $\mathrm{Gd}$ element for $\mathrm{Pb}$ in $\mathrm{Pb}_{8} \mathrm{Na}_{2}\left(\mathrm{PO}_{4}\right)_{6}$ is illustrated according to the following scheme:

$$
2 \mathrm{~Pb}^{2+}+\bullet \rightarrow 2 \mathrm{Gd}^{3+}+\mathrm{O}^{2-},
$$

occur at $x=1.0( \pm 0.05)$.

The decreases of the cell parameters $a$ and $c$ with increase of $x$ level with the substitution of lead in apatite structure is in agreement with the difference in the ionic radii of $\mathrm{Pb}^{2+}$, and $\mathrm{Gd}^{3+}$ ions (ionic radii of
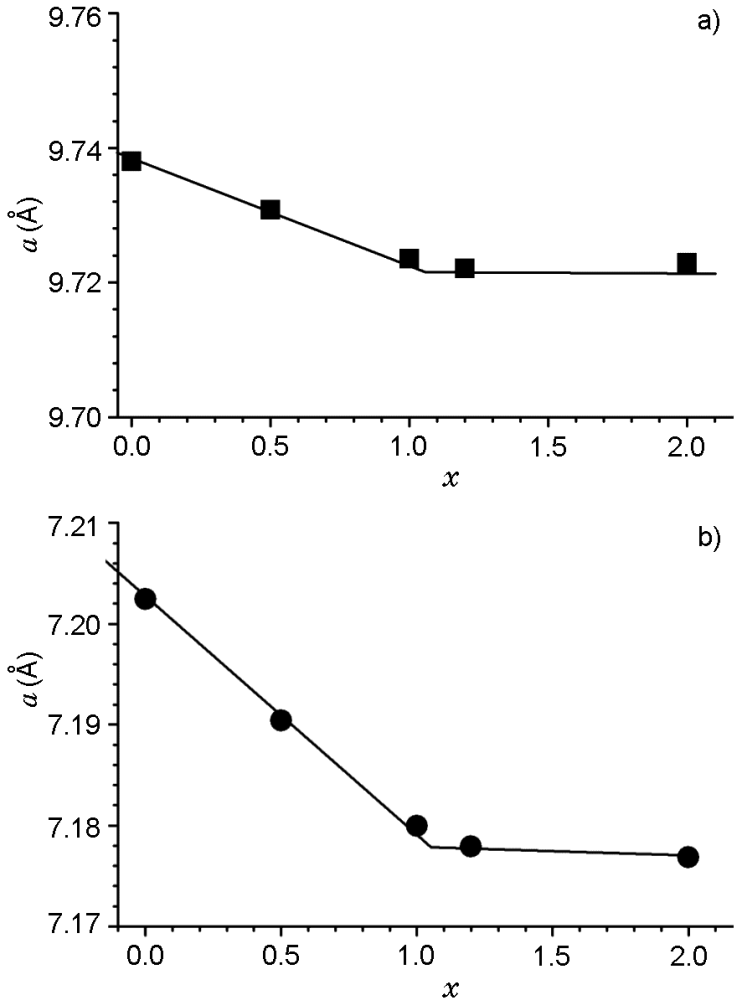

Fig. 2. Dependence of the lattice parameters $a$ (a) and $c$ (b) on the degree of substitution in $\mathrm{Pb}_{(8-\mathrm{x})} \mathrm{Gd}_{\mathrm{x}} \mathrm{Na}_{2}\left(\mathrm{PO}_{4}\right)_{6} \mathrm{O}_{\mathrm{x} / 2}$.

lead ion $\mathrm{Pb}^{2+}(1.330 \AA)$ is larger than ionic radii of gadolinium ion $\mathrm{Gd}^{3+}(1.076 \AA)$ ) [23].

In the second method (disappearing phase), the intensity of a largest reflection of a non-apatitic phase (phosphate gadolinium $\mathrm{GdPO}_{4}$ ) in the annealed sample is plotted VS the gadolinium amount in the system heterogeneous region. Extrapolation of this linear relationship to the intersection with the abscissa axis (intensity $=0$ ) gives an assessment for the homogeneity region limit. In Fig. 3, such kind of an extrapolation shows $x_{\max }$ at 0.97 in the system $\mathrm{Pb}_{8-\mathrm{x}} \mathrm{Na}_{2} \mathrm{Gd}_{\mathrm{x}}\left(\mathrm{PO}_{4}\right) 6 \mathrm{O}_{\mathrm{x} / 2}$ in good agreement with the value obtained by the first method (bend (inflection) method), as shown in Fig. 2. 


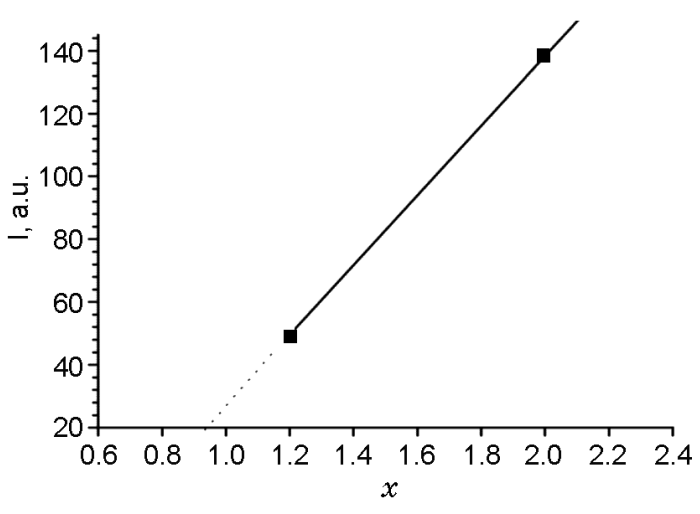

Fig. 3. Plot of the intensity of the phosphate gadolinium $\mathrm{GdPO}_{4}$ (120) reflection VS degree of substitution, $x$.

The results obtained from refinement of the crystal structure for some samples $(x=$ 0.0 and $x=0.5$ ) of the $\mathrm{Pb}_{8-\mathrm{x}} \mathrm{Na}_{2} \mathrm{Gd}_{\mathrm{x}}\left(\mathrm{PO}_{4}\right) 6 \mathrm{O}_{\mathrm{x} / 2}$ system are presented in Fig. 4 and in Tables 2 and 3 . The refinement of the structure by the Rietveld method was measured for a composition of $x=0.5$ with 830 reflections and 36 parameters. Factors of reliability were: 9.090 (Rp); 8.870 (Rf); 9.650 (Rb); $2.141\left(\mathrm{X}^{2}\right)$.

Previously, it was shown that the cations in the M1 sites are shorter cation-cation lengths in the apatite structure than cations in the triangular M2 positions demarcating the structural tunnels [12].

The preferential location of gadolinium in the M2 positions results in a decrease in the mean $\mathrm{Pb}-\mathrm{O}$ distances because of powerful electrostatic attraction in the M2 sites coordination polyhedral which is occupied by $\mathrm{Gd}^{3+}$ ion with higher charge and smaller size. The preferential location of $\mathrm{Gd}$ in the $\mathrm{Pb} 2$ positions results in decreasing in the mean $\mathrm{Pb}(2)-\mathrm{O}(1,2,3)$ distances due to higher electrostatic attraction in the $\mathrm{Pb} 2$ coordination polyhedral occupied by gadolinium Gd ions with higher charges and smaller sizes, and this causes an increase in the distances $\mathrm{Pb}(1)-\mathrm{O}(1,2,3)$. The presence of $\mathrm{Gd}(2)-\mathrm{Gd}(2)$ distances (too short distances) in the structure of solid solutions is found to exceed $4 \AA$ in dimensions, which allows to predict the luminescent properties in them. In spite of that, the distances Pb2$\mathrm{Pb} 2$ in the triangles do not change observably because they depend on either the ionic radius of $\mathrm{Gd}$ or the degree of substitution $(x)$. So, the substitution of $\mathrm{Gd}$ element for $\mathrm{Pb}$-containing lead apatite structure behaves quite differently from that in calcium or strontium apatite structures.

Results for some samples (wt. \%) of system $\mathrm{Pb}_{8-\mathrm{x}} \mathrm{Na}_{2} \mathrm{Gd}_{\mathrm{x}}\left(\mathrm{PO}_{4}\right)_{6} \mathrm{O}_{\mathrm{x} / 2}$ which are exam-

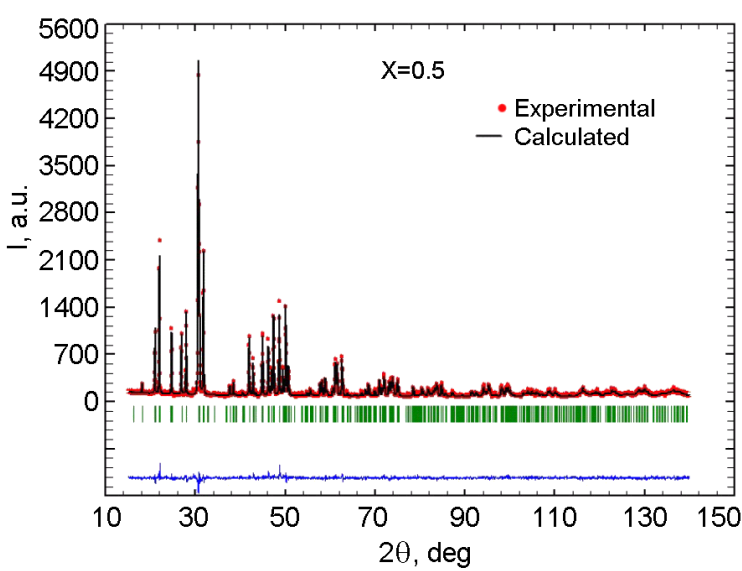

Fig. 4. The experimental and calculated X-ray diffraction patterns, as well as their difference for the sample composition $\mathrm{Pb}_{7.5} \mathrm{Gd}_{0.5} \mathrm{Na}_{2}\left(\mathrm{PO}_{4}\right)_{6} \mathrm{O}_{0.25}$.

ined by SEM exposed particles at $10 \mu \mathrm{m}$ are presented in Fig. 5 and table 4. Due to the fact that lead oxide under sublimation conditions can sublimate, semi-quantitative elemental analysis for $\mathrm{Na}, \mathrm{Pb}, \mathrm{Gd}$ and $\mathrm{Na}$ contents for compositions with $x=0.0$ and $x=0.5$ were performed. As can be seen from data, the found composition of elements $(\mathrm{Pb}, \mathrm{Na}, \mathrm{Gd}, \mathrm{P}$ and $\mathrm{O})$ are in satisfactory agreement with the calculated composition. Fig. 5 shows that the elements are practically uniformly distributed over the surface of the particle, which indicates the homogeneity of the sample. Some inhomogeneity can also be noticed on the surface which can be associated with the surface relief of particle.

IR spectra of lead apatite for studied samples $(x=0.0$ and $x=0.5)$ were measured in the region of the internal vibrations of phosphate groups and on two samples with composition inside the homogeneity region. All bands are shown in Fig. 6. The bands of phosphate $\mathrm{PO}_{4}{ }^{3-}$ anions are presented in fundamental vibrations, accordingly: $2\left(445 \mathrm{~cm}^{-1}\right) ; \quad 3(987,1051)$ and 4 $(539,580)$. When the atoms of gadolinium Gd entering the structure, the frequencies increase by $4-8 \mathrm{~cm}^{-1}$. The wide different bands in the 3500 and $1600 \mathrm{~cm}^{-1}(x=0.5)$ region are due to vibrations in the molecules of adsorbed water. In addition, there is a band at $637 \mathrm{~cm}^{-1}$; perhaps, it refers to the vibrations caused by the bond of $\mathrm{Gd}-\mathrm{O}$ or liberation vibrations returned to the $\mathrm{OH}^{-}$ group, which are not part of the water. 


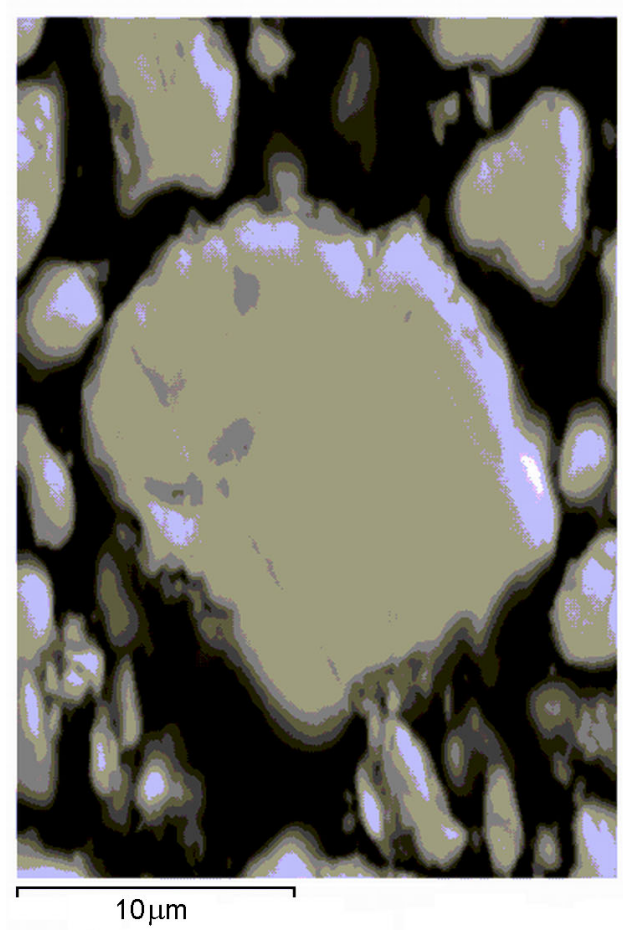

Fig. 5. Microphotography and distribution of elements over the surface for the sample composition $\mathrm{Pb}_{7.5} \mathrm{Gd}_{0.5} \mathrm{Na}_{2}\left(\mathrm{PO}_{4}\right)_{6} \mathrm{O}_{0.25}$.

\section{Conclusions}

In this study, samples were investigated by X-ray powder diffractometer, X-ray diffraction analysis of the powder by the Rietveld algorithm, scanning electron microscopy, and IR spectroscopy to determine the isomorphic substitution of gadolinium for lead in the following system: $\mathrm{Pb}_{8-x} \mathrm{Na}_{2} \mathrm{Gd}_{x}\left(\mathrm{PO}_{4}\right)_{6} \mathrm{O}_{x / 2}$. The boundaries of substitutions and the regularities of their changes are determined depending on the size of the ions that are substituted. The influence of substitutions on the crystalline structure of solid solutions were studied, in particular. It was possible to predict the presence of luminescent properties in them. It has been established by X-ray powder diffraction that the limit substitution of gadolinium for lead in lead apatite structure from $x=0.0$ to $x=1.0$ annealed at $900{ }^{\circ} \mathrm{C}$ for $7 \mathrm{~h}$. Because gadolinium ion $\mathrm{Gd}^{3+}$ has a smaller crystal ionic radii (1.076 $\mathrm{A})$ than lead ion $\mathrm{Pb}^{2+}(1.330 \AA)$, the substitution caused a decrease in lattice unit cell parameters (inflection method) in the homogeneity region $(x=0.0-1.0)$ with good agreement with the value obtained from dis-

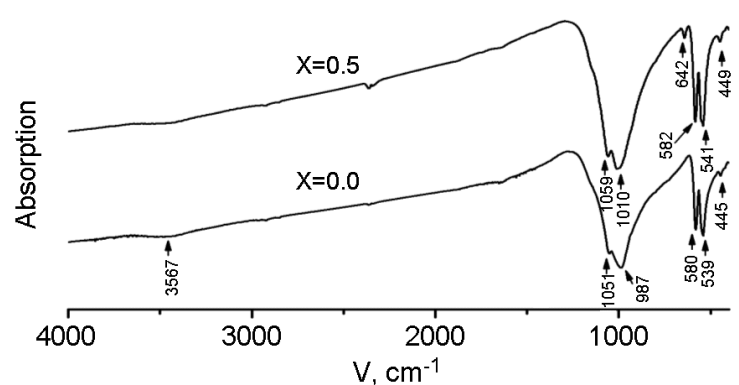

Fig. 6. Infrared spectra of samples of lead apatite $\mathrm{Pb}_{8-\mathrm{x}} \mathrm{Gd}_{\mathrm{x}} \mathrm{Na}_{2}\left(\mathrm{PO}_{4}\right)_{6} \mathrm{O}_{\mathrm{x} / 2}$ with $x=0.0$ and 0.5 .

appearing phase method ( $x_{\max }$ at 0.97$)$ which confirmed the value in inflection method. The results obtained from refinement of the crystal structure $\mathrm{Pb}_{8-\mathrm{x}} \mathrm{Na}_{2} \mathrm{Gd}_{x}\left(\mathrm{PO}_{4}\right)_{6} \mathrm{O}_{\mathrm{x} / 2}$ showed that the Gd occupies predominantly M2 (Pb2) positions, which leads to a decrease in the distances $\mathrm{Pb}(2)-\mathrm{O}(1,2,3)$, and an increase in the distances $\mathrm{Pb}(1)-\mathrm{O}(1,2,3)$. Too short distances $G d(2)-G d(2)$ may result in reducing of luminescence. Solid solution samples $\mathrm{Pb}_{7.5} \mathrm{Gd}_{0.5} \mathrm{Na}_{2}\left(\mathrm{PO}_{4}\right)_{6} \mathrm{O}_{0.25}$ and $\mathrm{Pb}_{8} \mathrm{Na}_{2}\left(\mathrm{PO}_{4}\right)_{6}$ were also examined by scanning electron microscopy SEM and they showed that the elements are practically uniformly distributed over the surface of 
the particle in a good agreement with the theoretical calculations. IR spectroscopy method shows that the bands of fundamental vibrations of the $\mathrm{PO}_{4}^{3-}$ anion shift by 4-8 $\mathrm{cm}^{-1}$ toward larger wavelength numbers, which indirectly indicates the presence of substitutions in the cation sublattice. So, it can be concluded that the isomorphs substitution of $\mathrm{Gd}$ for $\mathrm{Pb}$ in $\mathrm{Pb}_{8} \mathrm{Na}_{2}\left(\mathrm{PO}_{4}\right)_{6}$ under the scheme

$$
2 \mathrm{~Pb}^{2+}+\bullet \rightarrow 2 \mathrm{Gd}^{3+}+\mathrm{O}^{2-}
$$

in the compound $\mathrm{Pb}_{8-\mathrm{x}} \mathrm{Na}_{2} \mathrm{Gd}_{\mathrm{x}}\left(\mathrm{PO}_{4}\right)_{6} \mathrm{O}_{\mathrm{x} / 2}$ occur between $x=0.0-1.0$.

In this system, isomorphs substitution of $\mathrm{Gd}$ for $\mathrm{Pb}$ in the lacunary apatite manages very differently from what is observed in widely studied alkaline-earth hydroxyapatites and fluorapatites with filled hexagonal tubes. Therefore, substitution of $\mathrm{Gd}$ for $\mathrm{Pb}$ in $\mathrm{Pb}_{8} \mathrm{Na}_{2}\left(\mathrm{PO}_{4}\right)_{6}$ is controlled not only by locative and charge accommodation of samarium ions but also by the availability of the stereochemically active electron pair $6 \mathrm{~s}^{2}$ in the electronic distribution of lead ion $\mathrm{Pb}^{2+}$. The electrified conductivity with high temperatures depends on several factors: at a minimum on the degree of substitution, pointing the prospect of a transition from cationic to anionic conductivity.

Based on the all results obtained above, it is necessary to expand further studies about new functional materials with apatite structure.

\section{References}

1. Y. Pan, ME. Fleet, Mineralog. Soc. Amer., 48, 13 (2002)

2. D. Hammond, the Basics of Crystallography and Diffraction. Oxford University Press, Oxford (1997).

3. T.J. White, C. Ferraris, J. Kim, S. Madhavi, Mineralog. Soc. Amer., 57, 307 (2005).

4. Xi Liu, Sean R. Shieh, Michael E. Fleet et al., Amer. Mineralog., 93, 1581 (2008).
5. S.V. Dorozhkin, J. Matter. Res., 46, 135 (1999).

6. J. Zhang, H. Liang, R. Yu, et al., Mater. Chem. Phys., 114, 242 (2009).

7. S. Kale, S. Kahandal, S. Disale et al., Curr. Chem. Lett., 1, 69 (2012).

8. D. Grossin, S. Rollin-Martinet, C. Estourne's et al., Acta Biomater., 6, 577 (2010).

9. H. Yoshioka, Y. Nojiri, S. Tanase, Solid State Ionics, 179, 2165 (2008).

10. R. K. Osterheld, J. D. Hawthorne, J. Solid State Chem., 7, 106 (1973).

11. Fatima-Zahra Boujrhala, Bouchra Sghirb, Herbert Poellmannc et al., Acta Cryst (25th Europ. Crystallog. Meet., ECM 25, Istanbul), 65, 299 (2009).

12. Mohamed Toumi, Tahar Mhiri, J. Cer. Soc. Japan, 116, 904, (2008).

13. L.R.Morss, Chem. Rev., 76, 827 (1976).

14. M.E. Fleet, Y. Pan, J. Solid State Chem., 3, 78 (1994)

15. P.E. Mackie, R.A. Young, J. Appl. Crystallography, 6, 26 (1973).

16. M.E. Fleet, Y. Pan, Amer Mineralogist, 80, 329 (1995).

17. Evgeni I. Get'man, Alexey V. Ignatov, Mohammed A. B. Abdul Jabar et al., J. Inorg. Chem., 55, 2165 (2016).

18. I. Mayer, A. Semadja, V. Weiss, J. Solid State Chem., 34, 223 (1980).

19. J. Rodriguez-Carvajal, Program FullProf.2k, Version 2.20, Laboratoire Leon Brillouin (CEA-CNRS), France (2002).

20. T. Roisnel, J. Rodriguez-Carvajal, Materials Science Forum, Proc. Seventh European Powder Diffraction Conf. (EPDIC 7), Barcelona, 118 (2000).

21. R.M. Wilson, J.C. Elliot, S.E.P Dowker. Amer. Miner., 84, 1406 (1999).

22. A.S. Posner, A. Perloff, A.F. Diorio, Acta Cryst., 11, 308 (1958).

23. R. D. Shannon, Acta Crystallogr. Sect. A: Cryst. Phys., Diffr. Theor. Gen. Crystallogr, 32, 751 (1976).

24. N. Kachanov, L. Mirkin, Rentgenostrukturnyj analis; Mashgiz: Moscow (1960) [in Russian]. 